\title{
EFEKTIVITAS KONSELING REALITAS UNTUK MENINGKATKAN MOTIVASI BELAJAR LITERATUR REVIEW
}

\author{
Bilqis Rahmanda Hakim ${ }^{1,}$ Sri Mastutik ${ }^{2,}$ Abdul Muhid ${ }^{3}$ \\ UIN Sunan Ampel Surabaya ${ }^{1}$ \\ Email: bilqiselha@gmail.com \\ SMA A. WAHID HASYIM Tebuireng ${ }^{2}$ \\ Email: tuticraihan85@gmail.com \\ UIN Sunan Ampel Surabaya ${ }^{3}$ \\ Email: abdulmuhid@uinsby.ac.id
}

\begin{abstract}
ABSTRAK
Motivasi belajar siswa merupakan hal yang sangat diperlukan sehingga siswa mudah dalam menangkap infomasi atau pelajaran yang diberikan oleh pengajar atau guru. Motivasi merupakan respon dari suatu aksi, motivasi akan terangsang dengan adanya tujuan. Terdapat banyak pendekatan yang bisa dilakukan untuk meningkatkan motivasi belajar, salah satunya adalah pendekatan realitas. Pendekatan realitas sendiri bertujuan untuk membantu individu menjadi rasional dan memiliki mental yang kuat. Riset ini bertujuan untuk mengetahui efektivitas konseling dengan pendekatan realitas untuk meningkatkan motivasi belajar. Riset ini merupakan literatur review atau riset literature dimana peneliti mengkaji beberapa penelitian yang sudah dilakukan sebelumnya yang sesuai dengan tema penelitian kali ini.
\end{abstract}

Kata Kunci: Konseling Realitas, Motivasi

\section{THE EFFECTIVENESS OF REALITY COUNSELING TO INCREASETHE MOTIVATION FOR STUDYING LITELATURE REVIEW}

\begin{abstract}
Student learning motivation is indispensable so that students are easy to capture information or lessons given by teachers or teachers. Motivation is the response of an action, motivation will be aroused by the presence of goals. There are many approaches that can be taken to increase learning motivation, one of which is the reality approach. The reality approach itself aims to help individuals become rational and have a strong mentality. This research aims to find out the effectiveness of counseling with a reality approach to improve learning motivation. This research is a literature review or literature research where researchers review some previous research that is in accordance with the theme of this study.
\end{abstract}

Keywords : Reality Counseling, Motivation 


\section{PENDAHULUAN}

Elsye Irianti (2020) mengartikan motivasi sebagai kekuatan, motivasi, tuntutan, antusiasme, Atau mekanisme psikologis yang mendorong individu atau kelompok untuk mencapai prestasi tertentu sesuai dengan keinginannya sendiri. Wahyudi, n.d. meyakini bahwa motivasi merupakan dorongan hati yang mendorong orang untuk melakukan tindakan guna mencapai tujuan tertentu. Zamsir (2015) Motivasi ditandai dengan munculnya perasaan dan emosi manusia, artinya motivasi berkaitan dengan masalah psikologis, emosional yang dapat menentukan perilaku manusia. Karena motivasi merupakan respon terhadap perilaku, sehingga motivasi disebabkan oleh tujuan. Motivasi diperlukan dalamkegiatan pembelajaran untuk mendorong kemauan dan motivasi siswa terhadap kebutuhan belajarnya. Dengan motivasi siswa, mereka dapat mengikuti kegiatan belajar sejak awal. Dengan cara ini, apa yang telah dipelajari siswa akan lebih mudah diserap dan dipelajari.

Menentukan intensitas upaya belajar siswa membutuhkan motivasi. Menurut (Wibowo, ( 2014) motivasi mempunyai tiga fungsi yaitu: a) motivasi sebagai motivasi untuk bertindakan. Motivasi merupakan motor penggerak yang mempengaruhi sikap belajar siswa. b) Motivasi adalah kekuatan pendorong tindakan. Kekuatan pendorong psikologis yang menghasilkan sikap siswa merupakan kekuatan yang tidak terbendung, kemudian terwujud Berupa gerakan mental. c) Motivasi untuk memandu tindakan. Siswa yang termotivasi dapat memilih tindakan mana yang akan diambil dan tindakan mana yang diabaikan. Motivasi belajar siswa merupakan hal yang sangat diperlukansehingga siswa mudah dalam menangkap infomasi atau pelajaran yang diberikan oleh pengajar atau guru. Ada beberapa pendekatan yang mampu digunakan untuk meningkatkan motivasi belajar siswa, salah satunya adalah konseling individu dengan pendekatan realitas.

\section{LANDASAN TEORI}

(Winarni, 2017) tujuan konseling realitas adalah membantu individu mencapai kemandirian. Otonomi adalah keadaan kedewasaan yang memungkinkan masyarakat meninggalkan Dorongan lingkungan dan 
menggantinya dengan duorongan pribadi atau dari dalam diri sendiri (internal). Orang bertanggung jawab atas siapa mereka, siapa yang mereka inginkan, untuk membuat rencana yang realistis, dan untuk mencapai tujuan mereka.Konseling Metode realistis dirancang untuk membuat individu menjadi individu yang rasional dan kuat (Failasufah, 2015). Inti dari terapi realitas adalah bahwa setiap orang harus melakukannya bertanggung jawab atas tindakan yang mereka ambil (Corey, 2013). Pada dasarnya, metode ini menggunakan teknik yang melihat pada tindakan untuk membangkitkan pilihan individu untuk membuat pilihan tentang berbagai kejadian, daripada membiarkan orang lain mengontrol dirinya sendiri, karena individu harus mengontrol dirinya sendiri.

Konseling realitas dianggap mampu membantu menyelesaikan banyak permasalahan siswa, seperti Mutawally (2020) mengungkapkan bahwa, Konseling realitas dapat diterapkan di sekolah untuk membantu mengatasi masalah nomophobia. Konsultasi realitas merupakan salah satu jenis layanan bimbingan dan konsultasi yang perlu diterapkan di sekolah. pendekatan konsultasi realitas dapat mengurangi adiksi ketikamenggunakan smartphone yaitu konseli yang berinteraksi dengan mahasiswa (klien) dan memungkinkan mahasiswa (klien) untuk merealisasikan tuujuan sehingga mahasiswa (klien) dapat mengambil keputusan, sedangkan di Anggralisa (2015) menemukan tingkat signifikansi sebesar $(\alpha)$ 0,05 untuk membuktikan keefektifan layanan konseling kelompok yang menggunakan teknik konseling realitas terhadap kesulitan siswa dalam komunikasi interpersonal. Adapula penelitian yang dituliskan oleh Atin (2020) yang berjudul “pengaruh konseling kelompok realtas untuk meningkatkan kemampuan mengontrol emosii pada kelas VII MTS NW Tanak Maik 2019/2020 “ menghasilkan Skor terendah 132 skor tertinggi 140 dengan,mean rata-rata 135,6. Bahwa pemberian layanan konseling kelompok realitas dapat meningkatkan kemampuan mengontrol emosi pada siswa kelasVII MTs NW Tanak Maik. Sehingga dapat disimpulkan bahwa konseling realitas mampu membantu menyelesaikan banyak permasalahan siswa yang terjadi. 


\section{METODEPENELITIAN}

Metode yang digunakan berupa literature review dengan Pencarian jurnal dilakukan melalui database penyedia jurnal internasional milik Google yaitu Google Scholar (scholar.google.com). batasan mengambil jurnal yang digunakan dalam literature review. Dengan Kata kunci yang digunakan adalah "Teknik konseling realitas" dan "Motivasi belajar" Pada penelitian kali ini peneliti membahas tentang penerapan konseling realitas untuk meningkatkan motivasi belajar di masa pandemi covid-19.

\section{HASIL PENELITIAN DAN PEMBAHASAN Terapi Realitas}

Suatu bentuk psikoterapi yang berkembang selama periode ini. Terapi ini didasarkan pada kenyataan bahwa Individu memiliki hak Pilih dan bertanggungjawab atas apa yang telah dipilih (Rosida, 2017). Pada proses implementasi, konselor memiliki peran yang aktif dalam proses memberikan bantuan. Konselor adalah contoh atau master konseli. Dalam praktiknya, konselor juga menandatangani sejumlah kontrak untuk menyelesaikan masalah yang mereka hadapi dan membantu memfasilitasi proses konsultasi (Putri, 2019)

Teori dasar dari konseling psikologis realitas adalah "teori pilihan", yang menjelaskan fungsi individu seseorang dan berperan dalam masyarakat (kelompok atau masyarakat) melalui pilihan perilaku yang bertanggung jawab dan efektif. Teori pilihan menjelaskan bahwa semua yang akan kita lakukan adalah pilihan kita sendiri, yang harus kita lakukan hanyalah menentukan pilihan / memutuskan untuk melakukannya. Setiap tindakan kita adalah melakukan yang terbaik untuk mencapai kebutuhan yang ingin kita penuhi (Daud, 2013). Pada konseling realitas, Perilaku bermasalah dapat disamakan dengan "identitas gagal" yang dikemukakan oleh Rosida (2017) Identitas yang gagal memiliki ciriciri alienasi, eksklusi diri, dan irasionalitas, yaitu perilaku kaku, tidak objektif, lemah, dan layak. Bertanggung jawab, tidak mampu membuat pilihan yang realistis, kurang percaya diri dan menolak kenyataan. Menurut Rahman (2015) konseling realitas mengacu pada konseling yang menitikberatkan pada perilaku saat ini untuk mencapai masa depan daripada perilaku sebelumnya. Tentunya, hal ini akan membantu tutor untuk meningkatkan disiplin belajarnya bisa dengan menekankan pada tanggung jawab tutor sebagai siswa. 
Dalam proses pelaksanaan penggunaan terapi realitas untuk konsultasi terdapat beberapa cirri dari proses pelaksanaan, yaitu tidak terpaku pada kejadian-kejadian yang lalu dan sebelumnya. Namun, orang yang diajak berkonsultasi berfokus pada kehidupannya saat ini. Hal ini untuk mendorong konselor agar fokus pada penyelesaian Masalah yang dia hadapi sekarang sehingga tidak terpengaruh oleh peristiwa masa lalu yang menghambat perkembangannya saat ini Proses konsultasi seperti ini mudah untuk direncanakan dan diambil tindakannya untuk lebih menekankan pada perubahan perilaku yang lebih bertanggung jawab. Tahap terapi realistis Putri (2019) Proses konsultasi dalam pendekatan dunia nyata dipandu oleh dua elemen utama, yaitu menjadi pedoman untuk mendorong konselor agar berubah. Thompson dkk. Menyarankan delapan tahap konseling pendekatan realitas : 1) konselor menunjukkan interaksi dengan konseli (seorang teman), 2) memperhatikan perilaku saat ini, 3) mengeksplorasi kebiasaan konseli, dan 4) Siswa menilai atau mengevaluasi sendiri; 5) merancang perbuatan yang bertanggung jawab; 6) menciptakan komitmen; 7) tidak menerima permintaan maaf atau alasan terdakwa; 8) perlakuan selanjutnya (Gantina, Komalasari dan Wahyuni, 2011).Wubbolding Menggambarkan praktik terapi realitas merupakan terapi yang terdiri dari Dua bagian inti : (1) Lingkungan konseling dan (2) Prosedur khusus yang mengarahkan kepada perubahan perilaku. Kedua elemen tersebut adalah "siklus konsultasi. Siklus ini menggambarkan keseluruhan proses transformasi teori terapi realitas menjadi praktik.

Motivasi setiap siswa juga berbeda-beda. Motivasi Purwanita et al., (2013)adalah keadaan internal yang mendukung manusia untuk melakukan sesuatu. Suciana \& Rozali, (2014)menjelaskan "motivation is something that energizes, direct, and sustains behavior; its get students moving, points them in a particular direction, and keeps them going." Motivasi merupakan sesuatu yang dapat merangsang, membimbing, dan menopang perilaku. Motivasi akan mendorong siswa menjadi aktif dan membuat siswa menjadi terarah. Motivasi diri dapat berasal dari motivasi dalam yang disebut dengan motivasi internal, atau motivasi luar yang disebut dengan motivasi eksternal, yang telah dijelaskan oleh Dewi,(2013) motivasi meliputi motivasi internal dan motivasi eksternal. 
Motivasi bisa dipengaruhi oleh lingkungan internal atau lingkungan internal siswa itu sendiri, misalnya senang terhadap sesuatu (Halawati, 2017)

McClelland menyampaikan bahwa 14 motif berprestasi tersebut mengandung dua aspek, yaitu (1) menggambarkan Kekebalan dan kekhawatiran akan kegagalan, serta (2) menambah upaya yang bermanfaat dan mengharapkan kesuksesan. Namun, Traverse meyakini bahwa motivasi berprestasi memiliki dua kategori penting, yaitu harapan untuk sukses dan ketakutan akan kegagalan. Selain itu, dikatakan bahwa seseorang menjadi sukses atau gagal karena kebutuhan akan prestasi. Steers dan Porter mengemukakan ciri-ciri orang dengan kebutuhan berprestasi tinggi, yaitu sangat ingin mengerjakan tugas atau mencari solusi masalah, cenderung bekerja sendiri, dan cenderung memilih teman kelompok berdasarkan kemampuan daripada teman ketika bekerja dalam kelompok, Cenderung memilih target yang cukup sulit, ingin mendapatkan umpan balik tentang kinerja (umpan balik), dan ereka ingin mengetahui hasil kerja mereka, tidak peduli berhasil atau gagal.

Dari beberapa indikator klasifikasi yang dikemukakan oleh Hamzah B. Uno motivasi siswa dapat dilihat sebagai berikut: 1) keinginan dan keinginan untuk sukses, 2) motivasi dan kebutuhan untuk belajar, 3) harapan dan cita-cita untuk masa depan, 4) pembelajaran Apresiasi; 5) Adanya aktivitas yang menarik dalam pembelajaran; 6) Adanya lingkungan belajar yang kondusif (Dewi, 2013)

Pemberian motivasi ke siswa berarti akan menyebabkan siswa melakukan sesuatu atau ingin mengerjakan sesuatu. Jika ada motivasi maka hasil belajar akan menjadi yang terbaik. Selain itu, motivasi dapat dijadikan sebagai motor penggerak untuk berbisnis dan berprestasi. Adanya motivasi belajar yang baik akan memberikan hasil yang baik juga. Dengan cara demikian, melalui kerja keras terutama yang dilandasi motivasi, individu yang belajar akan mampu meraih hasil yang baik. Tingkat motivasi siswa nantinya akan menentukan tingkat pencapaiannya akademiknya (Rodiah, 2006)

Stevani (2016) Indikator motivasi belajar Itu dapat dibagi ke dalam kategori berikut: keinginan untuk sukses, motivasi dan permintaan untuk belajar, harapan dan cita-cita untuk masa depan, apresiasi terhadap pembelajaran, 
kegiatan yang menarik dalam pembelajaran, dan lingkungan belajar. Ini bagus bagi seseorang untuk belajar dengan baik.

Jenis motivasi Menurut Tayibu, Khaerun Nisa'a (2019) motivasi dibedakan menjadi dua jenis, yaitu: motivasi intrinsik adalah motivasi yang termasuk dalam lingkungan belajar dan memenuhi kebutuhan dan tujuan siswa; motivasi ekstrinsik adalah motivasi yang disebabkan oleh faktor-faktor. Situasi pembelajaran eksternal, seperti skor kredit, diploma, level hadiah, kompetisi medali, dan kompetisi negatif, semuanya diejek, diejek, dan dihukum.

Peran motivasi dalam belajar Motivasi mendorong perilaku, mempengaruhi dan mengubah perilaku. Oleh karena itu, menurut Tayibu, Khaerun Nisa'a. (2019) fungsi motivasi meliputi : mendorong perilaku atau tindakan. Tanpa motivasi tidak akan ada tindakan seperti belajar, motivasi adalah bimbingan. Ini berarti mengarahkan tindakan untuk mencapai tujuan yang diinginkan, dan motivasi adalah kekuatan pendorong. Ini bertindak sebagai mesin mobil. Besar kecilnya motivasi akan menentukan apakah pekerjaan itu cepat atau lambat.

\section{Efektivitas Konseling Realitas Untuk Meningkatkan Motivasi Belajar}

Pada studi tahun 2020 yang ditulis oleh Novia Solichah, berdasarkan intervensi yang sudah dilakukan, dalam evaluasi sesuai dengan observasi setelah konsultasi dan hasil Selama wawancara, subjek melihatkan perubahan yang baik. Sehingga, dapat disimpulkan bahwa konseling dengan terapi realitas dapat Atasi penundaan akademik dan bentuk sikap yang lebih positif saat menerima tugas ganda (Solichah, 2019)

Penelitian Failasufah (2015) membuktikan bahwa di MAN III Yogyakarta, bimbingan kelompok kehidupan nyata efektif digunakan untuk meningkatkan motivasi belajar siswa. Hal ini terlihat dari hasil penghitungan statistik output kelompok eksperimen sebelum dan sesudah dilakukan tes, skor motivasi belajar meningkat dari sebelum perlakuan menjadi setelah perlakuan. serta dalam penelitian yang dilakukan oleh Ginting (2017)membuktikan setelah diberi layanan konseling individual dengan teknik realitas pada siklus pertama dan siklus kedua, sikap positif siswa mengalami peningkatan Ginting (2017) Kemudian hasil penelitian yang dilakukan oleh Rosida (2017) pada 
penelitiannya mengugkapkan Konsultasi realitas WDEP (permintaan, lakukan, evaluasi, perencanaan) efektif dapat meningkatkan motivasi berprestasi siswa SMP (pembelajaran siswa SMP Negeri 1 Ngemplak Boyolali kelas VIII), penjelasan tersebut juga menunjukkan bahwa peningkatan motivasi berprestasi siswa meningkatkan prestasi prestasi Tidak berpengaruh. Peserta didik belajar secara signifikan.

\section{KESIMPULAN}

Berdasarkan hasil Literatur Review yang telah dipaparkan bahwa penerapan teknik konseling realitas dapat dilakukan untuk meningkatkan motivasi belajar. Konseling terapi realitas dirancang untuk memudahkan individu menjadi rasional dan kuat, serta diyakini efektif dalam meningkatkan motivasi belajar siswa. Proses konsultasi ini berfokus pada perubahan perilaku yang lebih bertanggungjawab dengan merencanakan dan melaksanakan tindakan ini.

Saran yang dapat diberikan :

1. Kepada guru BK untuk dapat mengaplikasikan teknik konseling realitas ini

2. Kepada siswa yang mengalami penurunan motivasi belajar, sehingga motivasi belajar siswa akan cenderung meningkat. Harapan kepada siswaagar dapat mempertahankan motivasi belajarnya.

3. Harapan bagi peneliti selajunya dharapkan dapat memperkaya kajian literature yang sudah ada dan semakin mengembangkannya

\section{DAFTAR PUSTAKA}

Atin, S. W. F. (Universitas H. (2020). Pengaruh Konseling Kelompok Realitas Untuk Meningkatkan Kemampuan Mengontrol Emosi Pada Siswa Kelas VII MTS NW Tanak Maik Tahun Pelajaran 2019 / 2020 Siti Wahida Fitri Atin Universitas Hamzanwadi Abstrak Penelitian ini bertujuan untuk mengetahui pengaruh. Jurnal Konseling Pendidikan.

Corey, G. (2013). Thoery and practice of counselling and psycotherapy (ninth edit). American board of professional psyvhology. https://katewalkertraining.com/wp-content/uploads/2019/03/9th-ed-GeraldCorey-Theory-and-Practice-of-Counseling-and-Psychotherapy-BrooksCole-2012.pdf 
Daud, A. (UIN S. U. (2013). Penanganan Masalah Konseli Melalui Konseling Realitas Ali. Journal of Chemical Information and Modeling, 53(9), 16891699.

Atin, S. W. F. (Universitas H. (2020). Pengaruh Konseling Kelompok Realitas Untuk Meningkatkan Kemampuan Mengontrol Emosi Pada Siswa Kelas VII MTS NW Tanak Maik Tahun Pelajaran 2019 / 2020 Siti Wahida Fitri Atin Universitas Hamzanwadi Abstrak Penelitian ini bertujuan untuk mengetahui pengaruh. Jurnal Konseling Pendidikan.

Corey, G. 2013. Thoery and practice of counselling and psycotherapy (ninth edit). American board of professional psyvhology. https://katewalkertraining.com/wp-content/uploads/2019/03/9th-ed-GeraldCorey-Theory-and-Practice-of-Counseling-and-Psychotherapy-BrooksCole-2012.pdf

Daud, A. (UIN S. U. (2013). Penanganan Masalah Konseli Melalui Konseling Realitas Ali. Journal of Chemical Information and Modeling, 53(9), 16891699.

Dewi, Putu Eka Krisna., dkk. 2013. Hubungan antara motivasi belajar dengan hasil belajar ekonomi pasa siswa kelas X di SMAN 1 Sawan tahun ajaran 2012-2013. 1-15.

Elsye Irianti. 2020. Upaya peningkatan motivasi belajar melalui pendekatan realitas pada siswa kelas IX F MTsN 5 Demak. Bimbingan Dan Konseling, $5(1)$.

Failasufah. 2015. Efektivitas konseling kelompok realit untuk meningkatkan motivasi belajar siswa (Studi Eksperimen pada Siswa MAN Yogyakarta III). Efektivitas Konseling ISSN 2442-8809, 1(2).

Fiah, R. El, \& Anggralisa, I. 2015. Efekitvitas Layanan Konseling Kelompok Dengan Pendekatan Realita Untuk Mengatasi Kesulitan Komunikasi Interpersonal Peserta Didik Kelas X MAN Krui Lampung Barat T.P 2015/2016. Jurnal Konseli BK Tarbiyah UIN RIL, Vol 2(1), 43-56.

Ginting, R. L. R. (Jurusan P. F. U. 2017. Upaya Meningkatkan Sikap Positif Siswa Melalui Konseling Individu Dengan Teknik Realitas di Kelas V SDN 075046 Lolofitu. Jurnal Psikologi Konseling, 10(1), 1-10.

Halawati, F. (Universitas I. (2017). Syntax Literate: Jurnal Ilmiah Indonesia Pengaruh kecenderungan otak kanan, lingkungan keluarga, dan motivasi belajar terhadap prestasi belajar matematika. 2541-0849, 2(10), 57-73. http://jurnal.syntaxliterate.co.id/index.php/syntax-literate/article/view/245

Mutawally. 2020. Kajian pengantar tentang konsep aplikasi dan tantangan. Persepsi Masyarakat Terhadap Perawatan Ortodontik Yang Dilakukan Oleh Pihak Non Profesional, 2(2), 1689-1699. 
Purwanita, N. W. H., Dantes, N., \& Setuti, N. M. 2013. Penerapan bimbingan kelompok untuk meningkatkan motivasi belajar siswa yang mengalami kesulitan belajar di kelas VII C SMPN 3 Singaraja. Jurnal Pendidikan Dan Kejuruan, $\quad 8(1), \quad 40-50$. https://ejournal.undiksha.ac.id/index.php/JJBK/article/viewFile/908/778

Putri, N. S. 2019. Konseling Kelompok dengan Terapi Realita dalam Menurunkan Prokrastinasi Akademik. KONSELI: Jurnal Bimbingan Dan Konseling (EJournal), 6(1), 49-56. https://doi.org/10.24042/kons.v6i1.4195

Rahman, D. H. 2015. Keefektifan teknik metafora dalam bingkai konseling realitas untuk meningkatkan harga diri siswa. Jurnal Konseling Indonesia, 1(1), 47-53. http://ejournal.unikama.ac.id/index.php/JKI

Rodiah. 2006. Penerapan Strategi Pembelajaran Otentik Dalam Meningkatkan Motivasi Belajar Matematika Siswa Kelas Vi Sd Negeri 008 Bumi Ayu. 131136.

Rosida, U. A. 2017. Konseling Realitas untuk Meningkatkan Motivasi Berprestasi dan Prestasi Belajar Peserta Didik SMP. 5(1). http://jurnal.fkip.uns.ac.id/index.php/counsilium

Solichah, Novia (Fakultas Psikologi, U. M. M. I. M. 2019. Konseling Pendekatan Terapi Realitas untuk Mengatasi Prokrastinasi Akademik. Penelitian Psikologi, $\quad$ 10(2), $12 . \quad$ https://doi.org/DOI: http://doi.org/10.29080/jpp.v11i1.346

Stevani. 2016. Analisis disiplin kerja guru dan motivasi beljara terhadap prestasi belajar siswa pada mata pelajaran IPS kelas VIII di SMPN 8 Padang. 2302 $1590 \quad E-I S S N$ : $2460 \quad-\quad 190 X, \quad 4(1), \quad 102-108$. https://doi.org/http://dx.doi.org/10.22202/economica.2015.v4.i1.625 Abstract

Suciana, D., \& Rozali, Y. A. 2014. Hubungan Dukungan Sosial dengan Motivasi Belajar pada Mahasiswa Universitas Esa Unggul. Jurnal Psikologi, 12(2), 43-47. https://ejurnal.esaunggul.ac.id/index.php/psiko/article/view/2398

Tayibu, Khaerun Nisa'a. Mahmud, Amrullah. 2019. Pengaruh motivasi belajar terhadap ketuntasan belajar sains melalui pelaksanaan program pembelajaran retrieval remedial murid SD di Kota Makassar. Jurnal Ilmu Pendidikan Dasar P-ISSN: 2620-5246 Dan e-ISSN: 2620-6307, 1(2), 326330. http://journal.stkip-andi-matappa.ac.id/index.php/dikdas

Wahyudi. (n.d.). Analisis kontribusi sikap ilmiah, motivasi belajar dan kemandirian belajar terhadap prestasi belajar mahasiswa prpodi pendidikan fisika STKIP PGRI Pontianak. Edukasi Matematika Dan Sains, 1(2).

Wibowo, Alex Harie (Pascasarjana FKIP UNS), Sunardi (Pascasarjana FKIP UNS), M. (Pascasarjana F. U. 2014. Hubungan Antara Motivasi Dan 
Disiplin Dengan Prestasi Belajar Siswa SMK Negeri 1 Pracimantoro Semester 1 Tahun Pelajaran 2012/2013. 2354-6441, 2(3), 323-332. http://jurnal.fkip.uns.ac.id

Winarni, M. A. 2017. Efektivitas Konseling Realitas Untuk Meningkatkan Penerimaan Diri Siswa Kelas Ix Smp Negeri 1 Tempel. Efektivitas Konseling Realitas.

Zamsir, D. 2015. Pengaruh Motivasi Belajar Terhadap Hasil Belajar Matematika Siswa SMP. Jurnal Pendidikan Matematika, 6(2). https://doi.org/10.32938/slk.v1i1.440 